\title{
SLK Gene
}

National Cancer Institute

\section{Source}

National Cancer Institute. SLK Gene. NCI Thesaurus. Code C131219.

This gene is involved in protein phosphorylation and apoptosis. 